\title{
INFLUENCE OF SOME INSECTICIDES ON THE EFFICIENCY OF Trichogramma SPP. (HYM., TRICHOGRAMMATIDAE ) TREATED AS IMMATURE STAGES INSIDE Sitotroga Cerealella EGGS AND INTRODUCED Pectinophora Gossypiella EGGS AFTER EMERGENCE. Manal A. A. El Sharkawy \\ Plant Protection Research Institute, ARC, Dokki,, Egypt
}

\begin{abstract}
Laboratory study was conducted to study the effect of some new insecticides on three different immature stages of three trichogrammatids and estimate its efficiency in parasitizing eggs of pink bollworm, Pectinophora gossypiella after the completion of its development and emergence. Field Recommended concentrations (FRCs) of three insecticides viz., trebon 30\% EC (Etofenprox), cygron 10\% EC (Alpha-Cypermethrin- Flufenoxuron), and raner 24 SC \% (Methoxyfenozide). The treated trichogrammatids were, Trichogramma evanescens, Trichogramma bactrae and Trichogramma brassicae, and the concerned immature stages at the time of treatment were prepupae, freshly formed pupae and mature pupae (3,5 and 7-days after parasitism). The study was conducted at $27 \pm 1^{\circ} \mathrm{C}, 80 \pm 5 \% \mathrm{R} . \mathrm{H}$.. Results showed that, the percentage of emergence due to treatments showed no significant differences between the three species of Trichogramma where the total means were; $63.93,62.17$ and $64.11 \%$ for T.evanescens, T. bactrae and T. brassicae, respectively. Regardless of the parasitoid species and the treated ages trebon had a severely impact on Trichogramma emergence (48.02\%), raner was the least harmful $(58.56 \%)$ whereas; cygron caused a moderate effect (54.58\%). The 3 days age was the less influenced age, as it gave the highest percentage of emergence where, total average was $60.31 \%$ ) after exposing to insecticides. Regardless the insecticide used, the percentage of adults' emergence was significantly differed by the age of immature stages for each Trichogramma specie, for example, In case of T. bactrae and $T$. brassicae, the 3 days age gave the higher percentage of emergence which being $56.8 \& 63.97 \%$, respectively, whereas, 7 days age gave the less percentage of emergence which retched $49.2 \& 45.03 \%$, respectively, and 5 days age gave the midst percentage which being $51.17 \& 53.13 \%$.

In contrast of the percentage of emergence, exposing any Trichogramma species at 7 days age (mature pupae) to insecticides had the harmless effect on the percentage of females compared to the other two ages.

Keyword: Insecticides, egg parasitoid, Trichogramma spp., PBW, Pectinophora gossypiella,
\end{abstract}

\section{INTRODUCTION}

The selection of an effective natural enemy for introduction into the field is a major issue in the development of biological control programs. Trichogrammatid egg parasitoids are considered to be the most useful biological control agents for inundative releases against lepidopterous pests (Singh and Jalali 1994). Trichogramma spp. has been extensively used as biological control agent. Bigler (1984) reported that 65 - 93\% reduction in larval infestations of the Europian corn borer, Ostrinia nubilalis in corn fields was achieved following Trichogramma releases during 1970 in Germany and 
Switzerland. Vornin and Grinbert (1981) reported a positive reduction of pests such as Loxstege spp. Agrotis spp. and Ostrinia spp. following Trichogramma releases. In China significant reductions in populations of Ostrinia spp., Heliothis spp. and Cnophalocis spp. as well as in crop damage were obtained by using Trichogramma as a biological control agent, (Li, 1984). Faria (2000) stated that Trichogramma pretiosum Riley was applied in Brazil for the control of several pests in corn, cassava and cotton crops. Furthermore, in the tomato crop, the control of the moth, Tuta absoluta was carried out in some countries, through inundative releases of Trichogramma pretiosum (Haji 1997). In Egypt, Trichogramma evanescens has been used successfully since 1984 as a biocontrol agent against different insect pests; the sugarcane borer, Chilo agamenon on sugar-cane and rice, the olive pest Prays oleae, the peach bud borer, Anarsia lineatella on peach and apricot, the grape-fruit worm, Lopezia botrana and the date fruit worms, Ephestia spp. on date palms (Abbas, 2004). T. bactrae was successfully used against Pectinophora gossypiella and Earais insulana (Shalaby et al 2002), AbdelHafez et al (2007), when pest densities exceed the thresholds, an occasional insecticide treatment is needed. Thus, pesticide intervention is considered essential in some situations to control high infestations of specific pests so as to reduce economic damage and pest spread, to other crops. Several insecticides that are widely used to suppress various pests can disrupt the effectiveness of these beneficial agents. It is less clear to what degree insecticides are disruptive with other non-target organisms (Gnanadhas 2010). Application of pesticides and Trichogramma spp. has historically been considered incompatible. Low rates of parasitism have been reported in several agricultural regions and this may be due, partly, to the extensive use of pesticides (Gullan and Cranston 1992). It is very important to study the side effect of pesticides on the natural enemies to exclude the ones that have harmful effect on such natural enemies (Shoeb 2005). Pesticides may limit the efficiency of the biological control agents and plant growth regulators can have deleterious effects on the parasitoids Trichogramma. Although pesticides do not have a specific site of action in arthropods, they can induce sub-lethal effects on reproduction or on the biological functions (Stefanello et al; 2008).

The aims of this study were to determine the best time to release the parasitoids and that to spray the insecticides, searching for safety or harmless insecticides to be used in sequence with Trichogramma releases and to determined the less effect stage of the parasitoid to these insecticides.

\section{MATERIALS AND METHODS}

According to the previous studies (Hutchison et al. (1990), Abd ElHafez, (1995)), which determined the developmental periods for different immature stages of $T$. evanescens and indicated that the incubation period was about one day (20-22 hr) and the developmental periods of larvae, prepupae and pupae were determined by $2,1.5$ and 3.5 days at $27 \pm 1^{\circ} \mathrm{C}$, respectively. Thus, the total developmental period (from egg to adult) 
required about 8 days. Three developmental stages of Trichogramma were defined to use in this experiment. These stages are newly full grown larva (3 days post parasitism), immature pupa ( 5 days post parasitism) and mature pupa (7 days post parasitism) that are ready to leave the host egg at the next day. These ages were chosen in this study because they are the ages used in our releases of Trichogramma. LiLi-Ying (1984) mentioned that, for integrated control of pests, it is very important to know the toxicity of the pesticides to each developmental stage of Trichogramma.

Insecticides used:

All tests were conducted with fresh solutions of three commercial insecticides prepared in distilled water; the field recommended concentration for each insecticide was used. The trade, common names and recommended field applications rates are explaining in Table (1).

Table (1): Details of insecticides used in the experiments:

\begin{tabular}{|c|c|c|c|c|}
\hline $\begin{array}{c}\text { Trade } \\
\text { name }\end{array}$ & $\begin{array}{c}\text { Common } \\
\text { name }\end{array}$ & Formulations & Recommended for : & ${ }^{*}$ Dosage \\
\hline Trybon & Etofenprox & $30 \% \mathrm{EC}$ & $\begin{array}{c}\text { white fly (bemisia tabaci) } \\
\text { (in Tomato) }\end{array}$ & $250 \mathrm{~cm}^{3} / \mathrm{feddan}$ \\
\hline Cygron & $\begin{array}{c}\text { Alpha- } \\
\text { Cypermethrin+ } \\
\text { Flufenoxuron }\end{array}$ & $10 \% \mathrm{EC}$ & $\begin{array}{c}\text { pink and spiny bollworms } \\
\text { (Pectinophora gossypiella } \\
\text { and Earias insulana) in } \\
\text { cotton. }\end{array}$ & $250 \mathrm{~cm}^{3} / \mathrm{feddan}$ \\
\hline Raner & Methoxyfenozide & $24 \mathrm{SC} \%$ & $\begin{array}{c}\text { Potato tuber moth } \\
\text { Phethoremea oberculella) } \\
\text { in potatoes }\end{array}$ & $\begin{array}{c}37.5 \mathrm{~cm} 3 / 100 \mathrm{~L} \\
\text { water }\end{array}$ \\
\hline
\end{tabular}

${ }^{*}$ Recom mended dose/feddan in $\mathbf{4 0 0}$ Liter water.

\section{The host and the parasitoid:}

Sitotroga cerealella, Pectinophora gossypiella eggs and Trichogramma spp. were obtained from the mass rearing in the integrated Pest Management Laboratory, Bollworms Research Department, Plant Protection Research Institute, ARC.

\section{Experimental techniques:}

1- Effect of insecticides on both emergence and the percentage of females (sex- ratio) emerged from treated host eggs:

For each Trichogramma spp., cards of Sitotroga cerealella parasitized eggs at different periods after parasitization i.e., 3, 5 and 7 days post parasitism were dipped for 15 seconds in each of the tested insecticides at the recommended concentration. The egg cards for control were dipped in water only. Each card contained 200-300 parasitized eggs; ten cards were used for each treatment. After allowing the treated fluid to dry at room temperature, each card was placed individually in a glass jars capped with cotton stoppers and incubated at $27 \pm 1^{\circ} \mathrm{C} \& 80 \pm 5$ R. H. until adults' emergence. Accordingly, the percentages of parasitoids emergence, females' longevity and females \% for the emerged treated parents ( $F 1$ generation) were calculated. 


\section{2- Effect of insecticides on vitality of emerged females from treated parasitized host eggs:}

The emerged parasitoid females, which succeeded to complete their development after treatment at the different three ages with the aforementioned insecticides, were examined to determine their efficacy in parasitizing new pink bollworm eggs (fecundity). Ten newly cards (untreated) of fresh $P$. gossypiella eggs were introduced to ten newly mated females individually in glass vials and supplied by $10 \%$ sugar solution as nutrition source. Females were observed daily until their die to determine their longevities. The parasitized host eggs were incubated at $27 \pm 1{ }^{\circ} \mathrm{C}$ and $80 \pm 5$ R.H., examined after five days to determine females' fecundity. Checked up after eight days was done to estimate the percentage of emergence, and females percentages among the produced progeny (F2 generation).

\section{Statistical analysis}

Analysis of variance (ANOVA) was conducted on collected data using Costat (1990) computer program software. Means were compared by Duncan's multiple range tests to separate the means (Snedecor \& Cochran 1980).

\section{RESULTS AND DISCUSSION}

\section{1-Effect of insecticides on the emergence of treated parasitoid:}

Results illustrated in table (1) presented the effect of insecticides on the emergence of adults' wasps and showed that, the three tested insecticides affected, significantly, on the percentage of Trichogramma adults emerged from treated host eggs in all immature stages of the three parasitoids as the percentages of emergence were reduced drastically which ranged from 75.1 to $37.8 \%$ compared with control ones which were ranged from 88.9 to $94.95 \%$. The percentage of emergence due to treatments showed no significant differences among the three species of Trichogramma, the corresponding total means were; 63.93, 62.17 and $64.11 \%$ for Trichogramma evanescens, Trichogramma bactrae and Trichogramma brassicae, respectively. Regardless of the parasitoid species and the treated ages trebon had a severely impact on Trichogramma emergence (48.02\%), raner was the least harmful one $(58.56 \%)$ whereas; cygron caused a moderate effect $(54.58 \%)$. The 3 days age was the less influenced age, as it gave the highest percentage of emergence the total average was $60.31 \%$ after exposing to the insecticides. Regardless the insecticide used, the percentage of adults' emergence was significantly differed by the age of immature stages for each Trichogramma specie, in case of $T$. bactrae and $T$. brassicae, the 3 days age gave the highest average percentage of emergence (56.8\& $63.97 \%$, respectively), whereas 7 days age gave the less percentage of emergence (49.2\& $45.03 \%$, respectively), and 5 days age gave the midst average percentage (51.17\& $53.13 \%)$. In case of $T$. evanescens, the average percentage of emergence showed no significant effect in 7 days age of immature stages (52.4\%) compared to 5 days age (51.6\%), (Fig. 1). Regardless of the treated parasitoid and the insecticide used, the 7 days age 
was the more affected age, as it gave the less percentage of adults' emergence as an average of $48.88 \%$ was recorded, whereas; the five days age gave a moderate percentage estimated by average of $51.97 \%$ (fig.2). Takada et al. (2001) mentioned that the difference of susceptibility of egg parasitoids to insecticides may be attributed from direct effect on the larval and pupal development and from the difference of food intake speed of the host contents. So it is further possibility that the residual insecticides outside of egg-shell disturb the emergence from host egg, this illustrated, why the 7 days age was the most influenced age in the percentage of adult emergence in the present study. The present study is also in agreement with Plewka et al. (1975), as they reported that insecticides did not penetrate the host eggchorion of Sitotroga cerealella, and Trichogramma spp. were affected only upon emergence from the eggs, and with Xiong et al. (1988) who suggested that the inhibition of adult emergence from $T$. japonicum seemed to be caused by insecticide residue on the host egg chorion.

Table (2): Effect of insecticides on emergence of treated trichogrammatids as immature stages.

\begin{tabular}{|c|c|c|c|c|c|}
\hline Insecticides & $\begin{array}{c}\text { Parasitoid } \\
\text { age }\end{array}$ & $\begin{array}{c}T . \\
\text { evanescens }\end{array}$ & $\begin{array}{c}T . \\
\text { bactrae }\end{array}$ & $\begin{array}{c}T . \\
\text { brassicae }\end{array}$ & $\begin{array}{c}{ }^{*} \text { Total } \\
\text { Mean士SD }\end{array}$ \\
\hline Trebon & $\begin{array}{l}3 \text { days } \\
5 \text { days } \\
7 \text { days } \\
\text { Control } \\
P=0.5 \\
\text { LSD }\end{array}$ & $\begin{array}{c}56.1 \pm 7.7^{\mathrm{D}} \\
47.1 \pm 5.4^{\mathrm{c}} \\
51.6 \pm 7.6^{\mathrm{c}} \\
90.2 \pm 1.6^{\mathrm{a}} \\
0.0000 \\
2.630\end{array}$ & $\begin{array}{c}42.9 \pm 3.2^{\mathrm{D}} \\
45.5 \pm 2.5^{\mathrm{b}} \\
45.1 \pm 3.8^{\mathrm{b}} \\
91.3 \pm 1.9^{\mathrm{a}} \\
0.0000 \\
2.644\end{array}$ & $\begin{array}{c}57.8 \pm 4.9^{\mathrm{D}} \\
48.3 \pm 3.1^{\mathrm{c}} \\
37.8 \pm 0.9^{\mathrm{d}} \\
93.8 \pm 1.4^{\mathrm{a}} \\
0.0000 \\
2.754\end{array}$ & *48.02 \pm 6.33 \\
\hline Cygron & $\begin{array}{l}3 \text { days } \\
5 \text { days } \\
7 \text { days } \\
\text { Control } \\
P=0.5 \\
\text { LSD }\end{array}$ & $\begin{array}{c}57.7 \pm 4.8^{\mathrm{b}} \\
50.8 \pm 3.5^{\mathrm{c}} \\
51.8 \pm 5.7^{\mathrm{c}} \\
93.5 \pm 2.1^{\mathrm{a}} \\
0.0000^{-8} \\
3.850\end{array}$ & $\begin{array}{c}64.6 \pm 1.5^{\mathrm{b}} \\
53.2 \pm 3.5^{\mathrm{c}} \\
47.8 \pm 2.2^{\mathrm{d}} \\
88.9 \pm 3.0^{\mathrm{a}} \\
0.0000 \\
2.432\end{array}$ & $\begin{array}{c}59.0 \pm 3.1^{b} \\
55.2 \pm 3.8^{c} \\
51.1 \pm 3.9^{d} \\
94.2 \pm 2.3^{a} \\
0.0000 \\
3.253\end{array}$ & ${ }^{*} 54.58 \pm 5.15$ \\
\hline Raner & $\begin{array}{l}3 \text { days } \\
5 \text { days } \\
7 \text { days } \\
\text { Control } \\
P=0.5 \\
\text { LSD }\end{array}$ & $\begin{array}{c}66.7 \pm 4.6^{b} \\
56.9 \pm 3.7^{c} \\
53.8 \pm 3.2^{d} \\
90.9 \pm 1.6^{a} \\
0.0000 \\
3.135\end{array}$ & $\begin{array}{c}62.9 \pm 4.7^{\mathrm{b}} \\
54.8 \pm 2.5^{\mathrm{c}} \\
54.7 \pm 1.9^{\mathrm{c}} \\
92.9 \pm 2.5^{\mathrm{a}} \\
0.0000 \\
2.816\end{array}$ & $\begin{array}{c}75.1 \pm 2.9^{b} \\
55.9 \pm 2.4^{c} \\
46.2 \pm 3.3^{d} \\
94.9 \pm 1.5^{a} \\
0.0000 \\
2.281\end{array}$ & ${ }^{*} 58.56 \pm 8.46$ \\
\hline \multicolumn{2}{|c|}{ Total Mean \pm SD } & $63.93 \pm 17.34$ & $62.17 \pm 18.71$ & $64.11 \pm 20.23$ & $\mathrm{~ns}$ \\
\hline
\end{tabular}

Means with the same letter in the same column are not significantly different. ${ }^{*}$ Total means without control ones. 
Table (3): Effect of insecticides on the percentage of females emerged from treated parasitized eggs.

\begin{tabular}{|c|c|c|c|c|c|}
\hline Insecticides & $\begin{array}{c}\text { Parasitoid } \\
\text { age }\end{array}$ & $\begin{array}{c}T . \\
\text { evanescens }\end{array}$ & $\begin{array}{c}T . \\
\text { bactrae }\end{array}$ & $\begin{array}{c}T . \\
\text { brassicae }\end{array}$ & $\begin{array}{c}{ }^{*} \text { Total } \\
\text { Mean } \pm S D\end{array}$ \\
\hline Trebon & $\begin{array}{l}3 \text { days } \\
5 \text { days } \\
7 \text { days } \\
\text { Control } \\
P=0.5 \\
\text { LSD }\end{array}$ & $\begin{array}{c}41.04 \pm 5.1^{\circ} \\
41.17 \pm 4.6^{b} \\
45.37 \pm 6.1^{b} \\
54.33 \pm 2.9^{a} \\
0.0000 \\
4.367\end{array}$ & $\begin{array}{c}39.89 \pm 2.9^{\mathrm{c}} \\
44.09 \pm 2.9^{\mathrm{b}} \\
46.41 \pm 3.2^{\mathrm{b}} \\
51.94 \pm 1.7^{\mathrm{a}} \\
0.0000 \\
2.445\end{array}$ & $\begin{array}{c}31.75 \pm 1.1^{\mathrm{c}} \\
29.19 \pm 4.2^{\mathrm{c}} \\
42.05 \pm 1.9^{\mathrm{b}} \\
50.49 \pm 2.9^{\mathrm{a}} \\
0.0000 \\
2.715\end{array}$ & ${ }^{*} 40.11 \pm 5.9$ \\
\hline Cygron & $\begin{array}{l}3 \text { days } \\
5 \text { days } \\
7 \text { days } \\
\text { Control } \\
P=0.5 \\
\text { LSD }\end{array}$ & $\begin{array}{c}36.59 \pm 4.8^{c} \\
36.40 \pm 4.2^{c} \\
45.91 \pm 5.1^{b} \\
51.78 \pm 3.4^{a} \\
0.0000 \\
3.996\end{array}$ & $\begin{array}{c}40.17 \pm 2.5^{0} \\
40.55 \pm 3.7^{b} \\
54.03 \pm 1.4^{a} \\
54.22 \pm 3.2^{a} \\
0.0000 \\
2.663\end{array}$ & $\begin{array}{c}41.31 \pm 3.9^{c} \\
35.99 \pm 1.8^{d} \\
45.0 \pm 2.2^{b} \\
51.33 \pm 2.1^{a} \\
0.0000 \\
2.502\end{array}$ & ${ }^{*} 41.77 \pm 5.8$ \\
\hline Raner & $\begin{array}{l}3 \text { days } \\
5 \text { days } \\
7 \text { days } \\
\text { Control } \\
P=0.5 \\
\text { LSD }\end{array}$ & $\begin{array}{c}44.46 \pm 3.5^{\circ} \\
35.60 \pm 2.8^{c} \\
45.03 \pm 2.8^{b} \\
54.35 \pm 2.4^{a} \\
0.0000 \\
2.565\end{array}$ & $\begin{array}{c}34.50 \pm 2.7^{\mathrm{c}} \\
45.64 \pm 2.7^{\mathrm{b}} \\
46.83 \pm 1.8^{\mathrm{b}} \\
55.23 \pm 2.2^{\mathrm{a}} \\
0.0000 \\
2.181\end{array}$ & $\begin{array}{c}32.30 \pm 2.6^{\mathrm{a}} \\
45.47 \pm 1.4^{\mathrm{c}} \\
48.06 \pm 5.7^{\mathrm{b}} \\
50.54 \pm 3.6^{\mathrm{a}} \\
.0000 \\
2.302\end{array}$ & 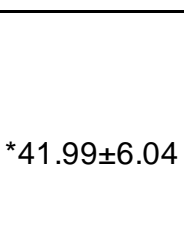 \\
\hline Tatal & $\pm S D$ & $44.34 \pm 6.6$ & $46.13 \pm 6.8$ & $41.96 \pm 7.92$ & ns \\
\hline
\end{tabular}

Means with the same letter in the same column are not significantly different *Total means without Control ones.

2- Effect of insecticides on the percentage of females emerged (sexratio) from treated parasitized eggs of Sitotroga cerealella:

Immature stages exposed to the tested insecticides were affected significantly on the percentage of the emerged females after exposing to the tested insecticides $\left(P=0.0000^{* * *}\right)$ with female less abundant at all treatments which caused a reduction in the percentage of females compared to untreated ones (Table: 3). Regardless of treated ages there were no significant differences between neither Trichogramma spp. (44.34, 46.13\& $41.96 \%$ for $T$. evanescens, $T$. bactrae and $T$. brassicae, respectively) nor the used insecticides $(40.1,41.77 \& 41.99 \%$ for trebon, cygron and raner, respectively). Whereas; significant differences between the three ages inside the same parasitoid specie regardless of the insecticide used. In contrast of the percentage of emergence, exposing any Trichogramma species at 7 days age (mature pupae) to insecticides had the harmless effect on the percentage of emerged females compared to the other two ages (Fig.1\& Fig. 2). 


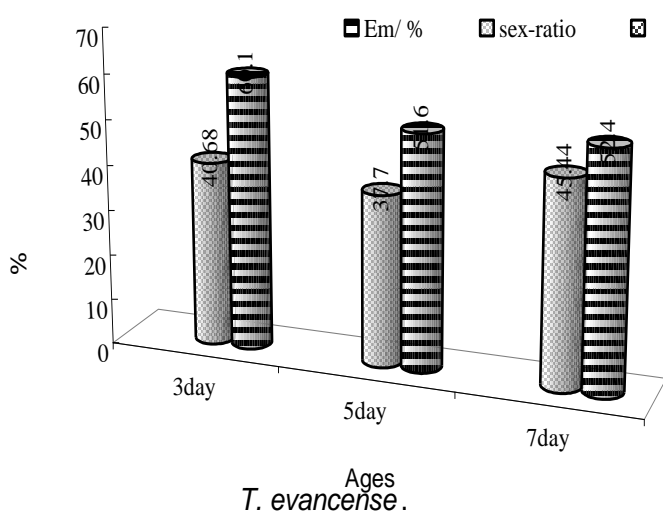

$T$.

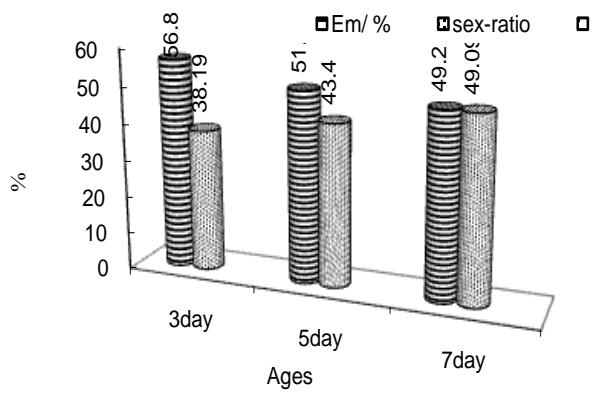

T. bactrae.

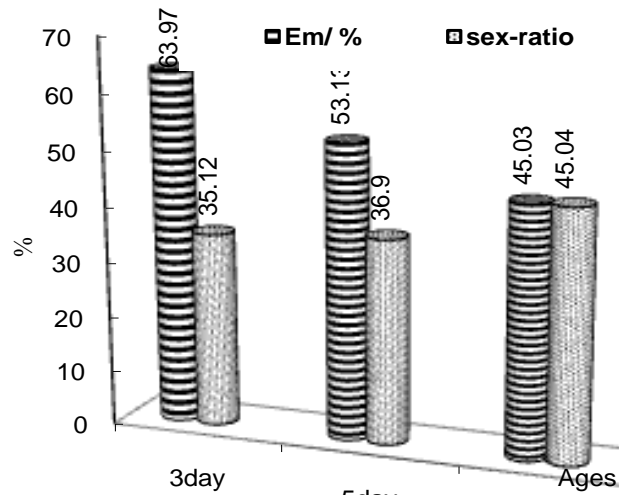

Fig. 1: Effect of insecticides on different species of Trichogramma. 


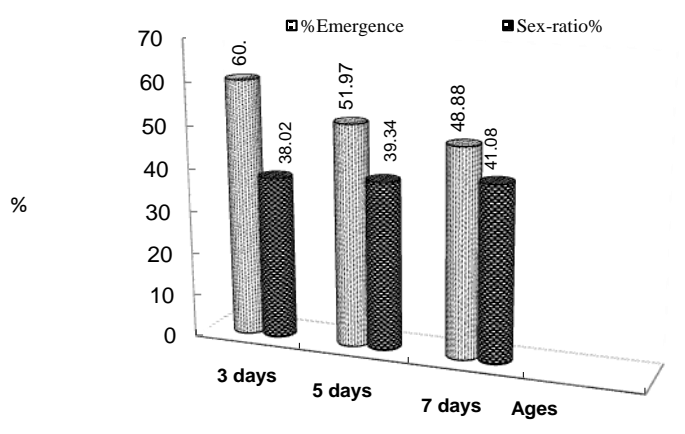

Fig.2: Comparison between the three ages regardless of the insecticides and parasitoid species.

\section{3- Effect of insecticides on vitality (fecundity \& longevity) of emerged females from treated parasitized eggs:}

\section{a. Effect on fecundity:}

Carmo et al (2010) stated that, evaluation of pesticides selectivity must not involve only effects on the viability of biological control agents but also on their fecundity (the number of progeny produced by treated females). Data inTable (4) revealed that fecundity for all produced females treated as immature stages with the three aforementioned insecticides at any of the treated stages was drastically reduced due to insecticidal action compared to control. Trebon was the most sever insecticide, and raner had the harmless effect, whereas, cygron caused the moderate effect. There were insignificant differences between the three species of Trichogramma in fecundity (38.56, 36.85\& 37.39progeny/ females for $T$. evanescens, $T$. bactrae and $T$. brassicae, respectively). Regardless of the treated parasitoid and insecticide used, exposing any of the three parasitoid species to insecticidal effects at 7 days age had the less severe impact on fecundity ( 36.15 progeny/ female) compared to 35.55\& 34.42 progeny/ female for 5 and 7 days age, respectively. (Fig.3). Varma and Singh (1987) found that phosalone and fenvalerate out of 9 tested insecticides were considered to be relatively safe to $T$. brasiliensis. Our present results about fecundity in accordance with those of Kawamura et al. (2001) who studied the toxicity of six Insecticides and found that adult female wasps, which emerged from host eggs treated with such two insecticides, had the ability to oviposit normally. The results are in contrast with those published by Vianna et al. (2009), who studied the effect of nine insecticides used in tomato production on two populatios of Trichogramma pretiosum Riley. They found that T.pretiosum emerged from Ephestia kuehniella eggs treated with esfenvalerate were not able to parasitize untreated eggs of this host. 


\section{b- Effect on females' longevity:}

Data represented in Table (4) showed that longevity of female of the three Trichogramma species varied, significantly, among treatments and was influenced by using different insecticides, and also by the age of the parasitoid at the time of exposure. In control, females treated as immature stages with water lived significantly the longest period. Treatment of Trichogramma species during 3 days age did not significantly reduce longevity of emerged females. Females longevity decreased gradually by increasing the age of immature stages of the parasitoids at the time of treatment as it estimated as $3,3.2$ \& 2.1 days in average for the 3,5 and 7 days age, respectively in case of the treatment of $T$. evanescens with trebon. As shown in Table (4) these were no significant differences among the three Trichogramma species. The mean longevities of emerged females were 3.07, 2.47, and 2.73 days for $T$. evanescens, $T$. bactrae and $T$. brassicae, respectively. The present study is in going in line with those of Geraldo et al. (2003) they reported that: Abamectin, lufenuron and pirimicarb decreased the lifetime of females exposed during the egg or larval stage, and in contrast with Shoeb (2010) who studied the effect of insecticides on T. evanescens and found that longevity of adults emerged from the treated eggs did not differ significantly from that of the control.

Table (4): Effect of insecticides on vitality ( fecundity and longevity) of the emerged females Trichogramma spp.

\begin{tabular}{|c|c|c|c|c|c|c|c|}
\hline \multirow[t]{2}{*}{ Insecticides } & \multirow{2}{*}{$\begin{array}{l}\text { Parasitoic } \\
\text { ges }\end{array}$} & \multicolumn{2}{|c|}{$\begin{array}{c}T . \\
\text { evanescens }\end{array}$} & \multicolumn{2}{|c|}{$\begin{array}{c}T . \\
\text { bactrae }\end{array}$} & \multicolumn{2}{|c|}{$\begin{array}{c}T . \\
\text { brassicae }\end{array}$} \\
\hline & & Fecundity & Longevity & Fecundity & Longevity & Fecundity & Longevity \\
\hline Trypon & $\begin{array}{l}3 \text { days } \\
5 \text { days } \\
7 \text { days } \\
\text { Control } \\
P=0.5 \\
\text { LSD }\end{array}$ & $\begin{array}{c}33.33 \pm 4.5^{\mathrm{c}} \\
37.17 \pm 4.3^{\mathrm{bc}} \\
40.90 \pm 2.4^{\text {ab }} \\
41.90 \pm 5.3^{\mathrm{a}} \\
0.0061 \\
3.839\end{array}$ & $\begin{array}{c}3.2 \pm 1.4^{\mathrm{ab}} \\
3.0 \pm 0.9^{\mathrm{bc}} \\
2.1 \pm 0.9^{\mathrm{c}} \\
4.1 \pm 1.1^{\mathrm{a}} \\
0.0000 \\
0.932\end{array}$ & $\begin{array}{c}32.0 \pm 2.17^{\mathrm{D}} \\
39.6 \pm 2.3^{\mathrm{a}} \\
39.1 \pm 4.4^{\mathrm{a}} \\
40.9 \pm 2.6^{\mathrm{a}} \\
0.0000 \\
2.285\end{array}$ & $\begin{array}{c}2.5 \pm 1.1 \mathrm{a} \\
1.8 \pm 0.4 \mathrm{~b} \\
1.1 \pm 0.3 \mathrm{c} \\
3.0 \pm 0.5 \mathrm{a} \\
0.0000 \\
0.594\end{array}$ & $\begin{array}{c}26.1 \pm 2.9 \mathrm{~d} \\
32.5 \pm 2.7 \mathrm{c} \\
40.6 \pm 3.6 \mathrm{~b} \\
45.3 \pm 1.9 \mathrm{a} \\
0.0000 \\
2.512\end{array}$ & $\begin{array}{c}3.30 \pm 1.1 \mathrm{a} \\
3.14 \pm 0.4 \mathrm{a} \\
1.29 \pm 0.5 \mathrm{~b} \\
3.43 \pm 0.9 \mathrm{a} \\
0.0001 \\
0.751\end{array}$ \\
\hline Cygron & $\begin{array}{c}3 \text { days } \\
5 \text { days } \\
7 \text { days } \\
\text { Control } \\
P=0.5 \\
\text { LSD }\end{array}$ & $\begin{array}{c}30.73 \pm 1.6^{\mathrm{b}} \\
25.77 \pm 1.3^{\mathrm{c}} \\
30.63 \pm 1.5^{\mathrm{b}} \\
47.00 \pm 3.6^{\mathrm{a}} \\
0.0000 \\
2.130\end{array}$ & $\begin{array}{c}3.20 \pm 1.0^{a} \\
2.44 \pm 0.5^{a b} \\
1.89 \pm 0.9^{b} \\
3.25 \pm 1.0^{a} \\
0.0000 \\
0.824\end{array}$ & $\begin{array}{c}33.00 \pm 2.6^{\mathrm{c}} \\
47.70 \pm 2.8^{\mathrm{b}} \\
32.76 \pm 1.6^{\mathrm{c}} \\
50.27 \pm 2.4^{\mathrm{a}} \\
0.0000 \\
2.165\end{array}$ & $\begin{array}{c}3.2 \pm 1.0 \mathrm{ab} \\
2.6 \pm 1.1 \mathrm{~b} \\
1.4 \pm 0.5 \mathrm{c} \\
3.6 \pm 0.5 \mathrm{a} \\
0.0000 \\
0.753\end{array}$ & $\begin{array}{c}35.84 \pm 2.5 b \\
32.47 \pm 3.3 c \\
37.50 \pm 2.7 b \\
43.62 \pm 3.8 \mathrm{~b} \\
0.0000 \\
2.895\end{array}$ & $\begin{array}{c}3.30 \pm 1.2 b \\
2.71 \pm 0.8 b \\
2.71 \pm 1.1 b \\
4.14 \pm 0.4 a \\
0.0184 \\
0.825\end{array}$ \\
\hline Raner & $\begin{array}{l}3 \text { days } \\
5 \text { days } \\
7 \text { days } \\
\text { Control } \\
P=0.5 \\
\text { LSD }\end{array}$ & $\begin{array}{c}40.3 \pm 0.7^{\mathrm{c}} \\
42.1 \pm 3.7^{\mathrm{bc}} \\
45.4 \pm 2.7 \mathrm{ab} \\
47.5 \pm 5.6 \mathrm{a} \\
0.0011 \\
3.391\end{array}$ & $\begin{array}{c}4.11 \pm 1.1^{a} \\
2.38 \pm 0.9^{b} \\
2.33 \pm 0.8 b \\
4.80 \pm 1.1 a \\
0.0000 \\
0.916\end{array}$ & $\begin{array}{c}26.46 \pm 2.3^{\mathrm{c}} \\
24.02 \pm 2.3^{\mathrm{c}} \\
36.50 \pm 3.9 \mathrm{~b} \\
39.93 \pm 1.9 \mathrm{a} \\
0.0000 \\
2.486\end{array}$ & $\begin{array}{c}2.43 \pm 0.8 b \\
2.14 \pm 0.9 b \\
2.20 \pm 1.0 b \\
3.70 \pm 0.8 \mathrm{a} \\
0.0020 \\
0.822\end{array}$ & $\begin{array}{c}34.02 \pm 1.8 b \\
29.57 \pm 1.2 \mathrm{c} \\
35.30 \pm 2.3 \mathrm{~b} \\
55.80 \pm 2.7 \mathrm{a} \\
.0000 \\
1.982\end{array}$ & $\begin{array}{c}2.33 \pm 1.2 \mathrm{ab} \\
1.75 \pm 0.7 \mathrm{~b} \\
1.78 \pm 0.8 \mathrm{~b} \\
2.90 \pm 0.99 \mathrm{a} \\
.0478 \\
0.881\end{array}$ \\
\hline Total $\mathrm{m}$ & $n \pm S D$ & $38.56 \pm 7.05$ & $3.07 \pm 0.9$ & $36.85 \pm 7.77$ & $2.47 \pm 0.81$ & $37.39 \pm 8.01$ & $2.73 \pm 0.82$ \\
\hline
\end{tabular}

Means with the same letter in the samecolumn are not significantly different. 


\section{1- Effect of insecticides on progeny produced (F2) by treated parents of $T$. spp:}

a. Progeny emergence:

Data in presented Table (5) showed that treatments of parents (F1) by insecticides didn't affect the percentage of emerged progeny (F2), as the percentage of emergence was above $90 \%$ and didn't differ significantly from control except for the treatment of $T$. evanescens at 5 and 7 days age with Raner, which produced $81.6 \& 88.9 \%$ emergence for un-known reason. The causation of increasing the percentage of emergence in the majority of treatments, because of the parasitoid host here was P. gossypiella eggs, and it was a favorable host eggs for Trichogramma in the aforementioned laboratory studies (Manal 1998).

Results in the present study disagree with Shoeb (2010), who found that, the respective values for the emergence rate for Gll decreased compared to $\mathrm{Gl}$ and the control, the recorded values were $68 \%, 62 \%, 63 \%$, $61 \%$ for GI \& $54 \%, 50 \%, 48 \%, 42 \%$ for Gll.

Table (5): Emergence and female percentages in second generation of Trichogramma spp. treated with insecticides during immature stages (first generation).

\begin{tabular}{|c|c|c|c|c|c|c|c|}
\hline \multirow[b]{2}{*}{ Insecticides } & \multirow[b]{2}{*}{$\begin{array}{c}\text { Parasitoid } \\
\text { ages }\end{array}$} & \multicolumn{2}{|c|}{ T. evanescens } & \multicolumn{2}{|c|}{ T. bactrae } & \multicolumn{2}{|c|}{ T. brassicae } \\
\hline & & $\begin{array}{c}\text { Emergence } \\
\%\end{array}$ & $\begin{array}{c}\text { Females } \\
\%\end{array}$ & $\underset{\%}{E m e r g e n c e}$ & $\underset{\%}{\text { Females }}$ & $\begin{array}{c}\text { Emergence } \\
\%\end{array}$ & $\underset{\%}{\text { Females }}$ \\
\hline Trypon & $\begin{array}{l}3 \text { days } \\
5 \text { days } \\
7 \text { days } \\
\text { Control } \\
P=0.5 \\
\text { LSD }\end{array}$ & $\begin{array}{c}93.5 \pm 2.5 \\
92.8 \pm 2.3 \\
94.2 \pm 0.7 \\
93.6 \pm 3.8 \\
0.8832 \\
\text { ns }\end{array}$ & $\begin{array}{c}56.1 \pm 1.8^{a} \\
48.6 \pm 2.6^{\mathrm{b}} \\
41.3 \pm 3.1^{\mathrm{c}} \\
58.1 \pm 2.1^{\mathrm{a}} \\
0.0000 \\
2.235\end{array}$ & $\begin{array}{c}90.3 \pm 2.8^{\mathrm{b}} \\
90.9 \pm 2.1^{\mathrm{b}} \\
93.2 \pm 2.2^{\mathrm{a}} \\
93.8 \pm 1.0^{\mathrm{a}} \\
0.0047 \\
1.950\end{array}$ & $\begin{array}{c}62.5 \pm 2.0^{\mathrm{b}} \\
63.6 \pm 2.2^{\mathrm{b}} \\
62.8 \pm 1.9^{\mathrm{b}} \\
74.9 \pm 2.8^{\mathrm{a}} \\
0.0000 \\
2.026\end{array}$ & $\begin{array}{c}93.3 \pm 1.8 \\
93.2 \pm 1.9 \\
94.6 \pm 1.9 \\
93.9 \pm 2.1 \\
0.4670 \\
\text { ns }\end{array}$ & $\begin{array}{c}63.3 \pm 0.7^{\mathrm{a}} \\
56.5 \pm 2.8^{\mathrm{b}} \\
55.5 \pm 1.6^{\mathrm{b}} \\
63.9 \pm 3.4^{\mathrm{a}} \\
0.0000 \\
2.189\end{array}$ \\
\hline Cygron & $\begin{array}{l}3 \text { days } \\
5 \text { days } \\
7 \text { days } \\
\text { Control } \\
P=0.5 \\
\text { LSD }\end{array}$ & $\begin{array}{c}91.3 \pm 1.7 \\
90.6 \pm 3.0 \\
94.4 \pm 2.5 \\
93.4 \pm 2.9 \\
0.1396 \\
\text { ns }\end{array}$ & $\begin{array}{c}43.7 \pm 4.5^{b} \\
57.6 \pm 4.2^{\mathrm{a}} \\
45.1 \pm 2.1^{\mathrm{b}} \\
59.3 \pm 2.3^{\mathrm{a}} \\
0.0000 \\
3.274\end{array}$ & $\begin{array}{c}94.8 \pm 3.3 \\
94.1 \pm 2.4 \\
94.2 \pm 1.9 \\
93.9 \pm 1.8 \\
0.8729 \\
\text { ns }\end{array}$ & $\mid \begin{array}{c}63.0 \pm 2.2^{\mathrm{a}} \\
61.9 \pm 3.6^{\mathrm{a}} \\
45.5 \pm 1.0^{\mathrm{b}} \\
64.5 \pm 4.5^{\mathrm{a}} \\
0.0000 \\
2.870\end{array}$ & $\begin{array}{c}91.7 \pm 3.1^{\mathrm{b}} \\
94.6 \pm 1.6^{\mathrm{a}} \\
94.1 \pm 1.5^{\mathrm{a}} \\
94.8 \pm 2.3^{\mathrm{a}} \\
0.0358 \\
2.175\end{array}$ & $\begin{array}{c}62.3 \pm 1.2^{\mathrm{ab}} \\
61.4 \pm 3.6^{\mathrm{b}} \\
53.7 \pm 3.2^{\mathrm{c}} \\
64.5 \pm 2.4^{\mathrm{a}} \\
0.0000 \\
2.384\end{array}$ \\
\hline Raner & $\begin{array}{l}3 \text { days } \\
5 \text { days } \\
7 \text { days } \\
\text { Control } \\
P=0.5 \\
\text { LSD }\end{array}$ & \begin{tabular}{|c|}
$93.9 \pm 3.0^{\mathrm{a}}$ \\
$81.6 \pm 4.3^{\mathrm{c}}$ \\
$88.9 \pm 3.4^{\mathrm{b}}$ \\
$93.9 \pm 3.0^{\mathrm{a}}$ \\
0.0000 \\
2.936
\end{tabular} & $\begin{array}{c}50.9 \pm 2.8^{\mathrm{c}} \\
55.4 \pm 1.7^{\mathrm{b}} \\
44.2 \pm 5.5^{\mathrm{d}} \\
62.5 \pm 4.1^{\mathrm{a}} \\
0.0000 \\
3.419\end{array}$ & $\begin{array}{c}91.7 \pm 2.9 \\
93.8 \pm 1.4 \\
92.5 \pm 2.1 \\
93.8 \pm 2.5 \\
0.8955 \\
\text { ns }\end{array}$ & $\begin{array}{c}53.2 \pm 4.5^{\mathrm{D}} \\
53.2 \pm 1.9^{\mathrm{b}} \\
51.4 \pm 1.3^{\mathrm{b}} \\
62.5 \pm 1.3^{\mathrm{a}} \\
0.0000 \\
2.236\end{array}$ & $\begin{array}{c}94.2 \pm 1.4 \\
92.1 \pm 2.5 \\
91.9 \pm 3.5 \\
91.5 \pm 2.9 \\
0.2446 \\
\text { ns }\end{array}$ & $\begin{array}{c}66.1 \pm 3.5^{a} \\
64.5 \pm 2.3^{a} \\
61.6 \pm 3.8^{\mathrm{b}} \\
65.5 \pm 2.1^{\mathrm{a}} \\
0.0266 \\
2.894\end{array}$ \\
\hline Total Me & $n \pm S D$ & $91.84 \pm 3.63$ & $51.9 \pm 7.17^{0}$ & $93.08 \pm 1.4$ & $59.92 \pm 7.8^{\mathrm{a}}$ & $93.3 \pm 1.23$ & $61.57 \pm 4.1^{2}$ \\
\hline
\end{tabular}

Means with the same letter in the same colum $n$ are not significantly different. LSD for Total mean longevities $=5.44$.

b. Females' percentage in produced ( F2) progeny (Sex-ratio):

In control, females' progeny dominated always that of males when parents' parasitoids were treated as immature stages with water, whereas; when parents treated as immature stages with insecticides; the percentage of produced females in progeny (F2) were decreased significantly. For example; 
exposing $T$. evanescens with Trebon at the ages of 3, 5 and 7 days age produced $56.1,48.6$ and $41.3 \%$ females compared with $58.1 \%$ females in control.

Delpuech and Meyet (2003) reported that there was a decrease in sex ratio for the offspring of treated females. This decrease in sex ratio was interpreted to be resulting from a decrease in fertilized eggs due to the perturbation of nerve transmissions induced by the insecticide. On the other hand, Suh et al. (2000) reported that, regardless of the developmental stage treated, none of the insecticides tested had a significant effect on the sex ratio.

\section{CONCLUSION}

1- Results indicated that effects of the tested insecticides were varied, Trebon showed a significant strong impact on the tested parasitoids compared to the untreated (control). While the negative effect of Raner on the tested parasitoid was relatively less with a significant high percentage of adult emergence. Whereas; Cygron caused amidst effect on the tested parasitoids compared to the other two used insecticides.

2- The 7 days age was the most influenced age, the 3 days age was the least age influenced with insecticides whereas; the 5 days age was moderately influenced.

It is important to point out that this experiments were conducting under laboratory conditions where the parasitoid was subscript to the highest pressure of insecticides, than, under field conditions; whereas; insecticides might lose their impact. Moreover, sunlight degradation plays an important role in the field that also helps to decrease the impact of pesticides on the beneficial arthropods observed in laboratory (Rocha \& Carvalho, 2004). Thus, there is a need for field confirmation of the laboratory results.

\section{REFERENCES}

Abbas, M.S.T.(2004): Successful applications Trichogramma evanescens (West.) for controlling certain insect pests in Egypt. 1 Arab Conference of Applied Biological pest control, Cairo, Egypt, 5-7 April 2004: 148(Abstract).

Abd El-Hafes, Alia (1995): A comparison of thermal requirements and some biological aspects of Trichogramma evanescens Westwood and Trichogrammatoidea bactrae Nagaraja reared on eggs of the pink and spiny bollworms. Annals Agric. Sci. Ain. Shams Univ., Cairo, 40 (2): 901-912.

Abd El-Hafez Alia, K. A. Hassan, Manal A.A. El-Sharkawy and H.A. Zedan (2007): Biological control of pectinophora gossypiella (saund.) and earias insulana (boisd.) in cotton fields at dakahlia governorate, egypt by augmentative releases of Trichogramma evanescens westwood. 
Bigler, F. (1984): Mass production and field application of Trichogramma maidis Pintureau \& Voegele against the European corn borer in Switzerland. AbstractVol. XVII. Intern. Cong. Ent., Hamburg, Germany, pp: 788.

Carmo, E.L. Do, A.F. Bueno, R.C.O.F Bueno, S.S. Vieira, M.M.P. Goulart and T.R. Carneiro, (2010): Selectivity of pesticides used in soybean crops to Trichogramma pretiosum Riley, 1879 (Hymenoptera: Trichogrammatidae) pupae. Arquivos do Instituto Biologico (Sao Paulo), 77(2): 283-290.

Costat Statistical Software. (1990): Microcomputer program analysis Version 4.20.Berkeley, CA: Cohort Software.

Delpuech, J. M. and Meyet, J. (2003). Reduction in the Sex Ratio of the Progeny of a Parasitoid Wasp ( $T$. brassicae) Surviving the Insecticide Chlorpyrifos. Archives of Environmental Contamination and Toxicology. 45: 203-208.

Faria, Jr. P.A.J. (2000). Resposta funcional de Trichogramma pretiosum Riley Tuta absoluta (Meyrick) (Lepidoptera: Gelechiidae), efeitoda idade do hospedeiro:An. Soc. Entomol. Bras., Itabuna, 29(1): 85-93.

Geraldo, A. C., Paulo R. R., Luiz C. D. R., Jair C. M., Loriney C. F. and Carvalho C. E., 2003: Side-effects of insecticides used in tomato fields on Trichogramma pretiosum (Hymenoptera, Trichogrammatidae). Acta Scientiarum. Agronomy Maringá, 25(2):275-279.

Gnanadhas Preetha1, Thiyagarajan Manoharan1, Johnson Stanley and asthakutty Kuttalam1 (2010): Impact of Chloronicotinyl Insecticide, Imidacloprid on egg, egg-larval and larval parasitoids under laboratory conditions Journal of Plant Protection Research 50 (4) 535-540.

Gullan, P.J. and P.S. Cranston, 1992. The Insects: An Outline of Entomology. Chapman \& Hall, New York NY, USA.

Haji, F.N.P. (1997): Controle biológico da traça do tomateiro com Trichogramma no Nordeste do Brasil. In: PARRA, J.R.P.; ZUCCHI, R.A. Trichogramma eocontrole biologic aplicado. Piracicaba: FEALQ, cap. 12:319-324.

Hutchison, W. D.; M. Moratorio and J. M. Martin (1990): Morphology and biology of Trichogrammatoidea bactrae (Hymenoptera: Trichogrammatidae), imported from Australia as a parasitoid of pink bollworm (Lepidoptera: Gelechiidae) eggs. Ann. Entomol. Soc. Am., 83: 46-54.

Kawamura, S., Y. Takada and T.J. Tanaka, 2001: Effects of various insecticides on the development of the egg parasitoid Trichogramma dendrolimi (Hymenoptera: Trichogrammatidae). J. Eco Entomol., 94(6): 1340-1343.

Li L., (1984): Research and utilization of Trichogramma in China, Im. P. L. Adkisson \& Ma Shijun (eds) Proe. Chinese Aead Sci. Joint U. S. Nat. Acad. Sci. Symp. On Biological Control of Insects. Science press, Beijing, China, P. 204-23 
Li, Li-Ying, (1994): Worldwide use of Trichogramma for biological control on different crops: a survey, pp: 37-54. In: Wajnberg E. and S.A. Hassan, eds. Biological control with egg parasitoids. CAB International, Wallingford. 3(1): 31-38.

Manal (1998): Effect of host species and kind of food on two Trichogramma spp. M. Sc.

Plewka, T., J. Kot and T. Krukierek, 1975: Effect of insecticides on the longevity and fecundity of Trichogramma evanescens (Hymentoptera: Trichogrammatidae). Pol. Ecol. Stud., 1: 197-210.

Rocha, L.C.D. and Carvalho, G. A, (2004): Adaptação da metodologia padrão da IOBC para estudos de seletividade com Trichogramma pretiosum Riley, 1879 (Hymenoptera: Trichogrammatidae) em condições de laboratório. Acta Scientiarum Agronomy, 26(3): 315-320.

Shalaby, F.F.; Alia Abd El-Hafez; E.F. El-Khayat and Manal A.A. El-Sharkawy (2002): Applied control of Pectinophora gossypiella (Saund.) and Earias insulana (Boisd.) in cotton fields by releasing Trichogrammatoidae bactrae Nagaraja. $2^{\text {nd }}$ International Conference, PPRI, ARC, Cairo, Egypt, 21-24 Dec., 1: 402-411.

Shoeb Mona, A., (2010): Effect of some insecticides on the immature stages of the egg parasitoid Trichogramma evanescens West. (Hym., Trichogrammatidae ). Egypt. Acad. J. biolog. Sci., 3(1): 31-38.

Shoeb, Mona A., (2005): Comparativeness of chemical, natural and bacterial insecticides on some biological aspects of the egg parasitoid Trichogrammaevanescens (West.) J. Agric. Sci. Mansoura Univ., 30(8): 4821-4826.

Singh S.P., Jalali S.K. (1994): Trichogrammatids. Technical Bulletin No. 9, Project Directorate of Biological Control, Bangalore, 93 pp.

Snedecor, G. W. and W. G. Cochran (1980): Statistical Methods, $2^{\text {nd }}$ Ed. The lowa State Univeristy Press, Ames, lowa, pp. 318.

Stefanello Junior, G.J., A.D. Grutzmaacher, D.D.Grutzmacher, C.A.B. de Lima, D.O. Dalmozo and M.D.F. Paschoal, (2008): Selectivity of herbicides registered on corn to Trichogramma pretiosum (Hymenoptera: Trichogrammatidae). Planta daninha 26: 343-351.

Suh, C. P., D. B. Orr, and J. W. Van Duyn (2000): Effect of Insecticides on Trichogramma exiguum (Trichogrammatidae: J. ymenoptera) Preimaginal Development and Adult Survival Econ. Entomol. 93(3): 577-583.

Takada, Y.; S. Kawamura, and T. Tanaka (2001): Effects of various insecticides on the development of the egg parasitoid Trichogramma dendrolimi (Hym: Trichogrammatidae). J. Econ. Entomol., 94(6): 13401343.

Varma, G. C. and P. P. Singh (1987): Effect of insecticides on the emergence of Trichogramma brasiliensis (Hymenoptera: Trichogrammatidae) from parasitized host eggs. Entomophaga, 32(5): 443-448. 
Vianna UR, Pratissoli D, Zanuncio JC, Lima ER, Brunner J, Pereira FF, and SerrãoJE. (2009): Insecticide toxicity to Trichogramma pretiosum (Hymenoptera:Trichogrammatidae) females and effect on descendant generation. Ecotoxicology (London, England) 18(2):180-6.

Voronin K. F. and Grinberg, A. M. (1981): The current status and prospects of Trichogramma Utilization in the USSR. P. 49-51, In. J. R. Coulson (ed.). Proe. Joint American Soviet Conf. on Use of Beneficial Organisms in the Control of Crop Pests. Ent. Soc. Amer. College Park, Maryland.

Xong, H.; L. Kia- Huang; L. Yan-Fen.; M. Qi-Zhi.; L. Li-Ying and Z. Li-Chu. (1988): Preliminary study on the selection for insecticide-resistant strain of Trichogramma japonicum Ashmead, PP. 411-418. In $\mathrm{J}$. Voegele, J. K. Waage, and J. C. van Lenteren, Trichogramma and other egg parasitoids Antibes INRA, Paris.

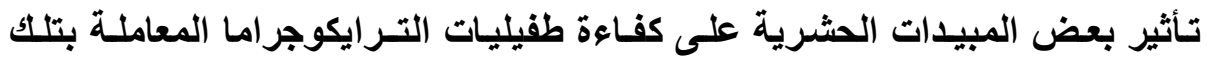

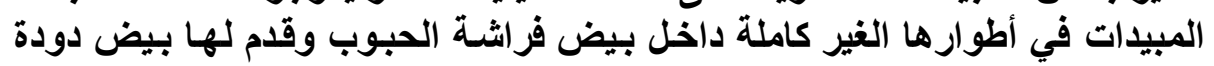

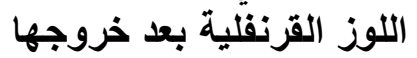

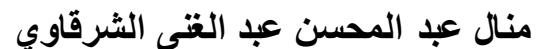

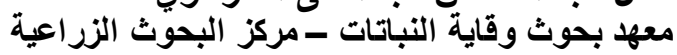

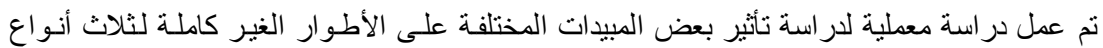

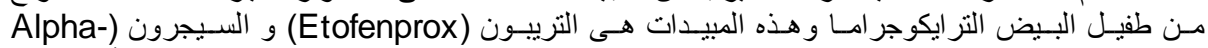

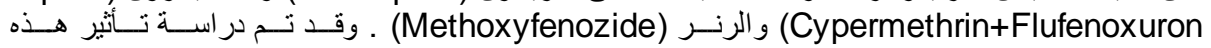

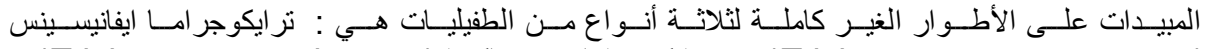

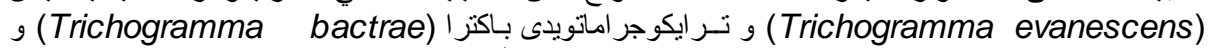

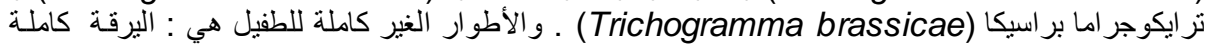

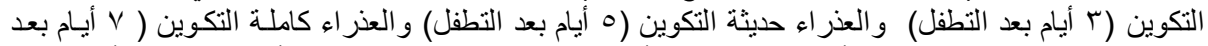

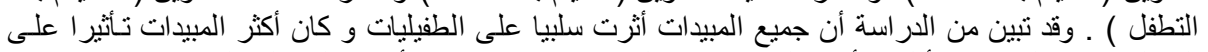

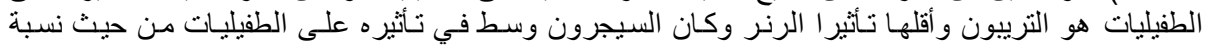

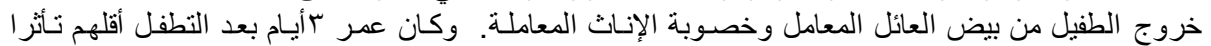

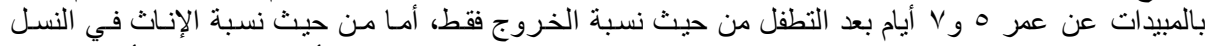

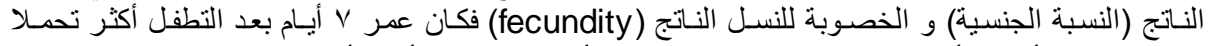

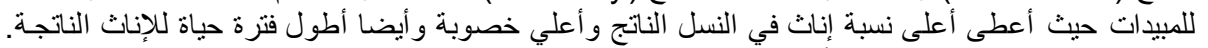
لم توجد فروق معنوية بين الثثلاث أنواع من الطفيل في مدى تحملها للمبيدات. 